\title{
HIGH DENSITY ARCHITECTURE AS LOCAL FACTORY OF CIRCULAR ECONOMY
}

\author{
${ }^{1}$ LUIS M. VALENZUELA, ${ }^{2}$ RODRIGO TISI \& ${ }^{3}$ LUCAS HELLE \\ ${ }^{1}$ Associate Professor, Director of Center for Territorial Intelligence at Universidad Adolfo \\ Ibáñez \& Associate Researcher at Centre for Social Conflict and Cohesion Studies. \\ ${ }^{2}$ Associate Professor \& DesignLab 's Director of Research at Universidad Adolfo Ibáñez. \\ ${ }^{3}$ Graduate Student at Universidad Adolfo Ibáñez.
}

\begin{abstract}
For at least two decades, Chile has witnessed intensive processes of urban regeneration, mainly by a densification of vast areas. This article offers a new review of residential densification, not through the lens of building height or architectural massiveness, but rather by considering residential density as an opportunity to introduce circular economy cycles on a local scale. The article supports the hypothesis that a building, with a high concentration of households, is a chance to induce a smallscale alternative, which is less time consuming and demands less coordination than other initiatives that require system-wide innovations. In order to better extract the maximum value from resources, to recover and regenerate products and materials, it seems common-sense to design a process as close as possible to where the resources are used, as well as look into the architectural design of residential buildings and evaluate the degree of needed adaption to transform high density architecture into a local factory of circular economy. Focusing on a single case study in the city of Santiago, as an exercise of adaptation, the aim is to create a waste reducing design, with the possibility of redefining products and services.
\end{abstract}

Keywords: architectural building recycling system, circular economy design, residential density

\section{INTRODUCTION}

Urban transformations of densities, firstly in the city of Santiago and subsequently in the other large metropolitan areas in Chile [1], have led to emerging density conflicts, quite unique and different from other Latin-American countries [2]. Recently, the real estate market has taken on a leading and aggressive role in the process of urban socioeconomic developments and the production of new urban structures. High residential densities, beyond drawing people from different residential origins to a particular neighborhood, cause a saturation of services, amenities and infrastructures. Understandably, concerns and critiques have surfaced in response to anticipated gentrification, as the evidence shows potential increases in rent levels, suggesting subsequent social displacement of low-income residents [3]. The purpose of the study, however, was to investigate the benefits of urban residential density from both a quantitative dimension and an ecological perspective. Assuming there is a new residential density as part of the urban production process, perhaps there is a certain density that could foster a more ecological and sustainable city transformation. Its objective was to define the ideal amount of urban density, to promote the incorporation of ecological systems within residential buildings.

What is analysed here, is the relationship between the production of urban structures in terms of their functioning for the real estate market and its capacity to become a link in the circular economy. The working hypothesis is that residential densification has the capacity to generate a particular urban structure of circular economy, where the presence of buildings simultaneously produces an urban residential densification, a process of recycling, and an energy production cycle. 


\section{REAL ESTATE \& WASTE}

\subsection{Real estate dynamics}

Since around 2000, the current transformation trend in Chilean cities has been tremendous, specifically in regards to the penetration of high-density residential buildings [4]. Overall, urban zoning policies have institutionalized the framework of a subsidiary state and a favorable real estate market regulatory framework, by which market-driven planning has developed targeted strategic urban areas. This has given cities a singular modernity, yet coupled with poor sustainability strategies and environmental planning, among other initiatives [5].

During the last decade, the value per square meter of apartments has continued to rise, evidencing the increasing demand for this type of housing, simultaneously contributing to greater urban density [3]. Although initially, high-rise residential development was partially restricted in the municipality of downtown Santiago, specifically during the 90's [5], highrises expanded throughout several neighboring municipalities, as their zoning plans did allow for this real estate model. Noteworthy, municipal incomes from building permits constitute a significant source of income for their budgets. Thus, promoting regulations favorable to high density buildings would contribute towards the increase of real estate investment and with it the potential to capture greater municipal revenues [6].

Therefore, land zoning has a direct impact on the organization of cities with long-term effects on the arrangement of its economic activity [7]. This indicates the underestimation of zoning's importance in shaping urban form in contemporary cities, but also, we suggest it understates its impact on sustainability. On a similar spatial scale, we also evaluate zoning's impact on present day housing prices.

According to the Chilean Ministry of Housing and Urbanism, in 2013, for every 4-5 houses demolished, an average of 95 apartments took their place. Thus, a building with that said quantity of apartments will be the base number for this applied exercise of architectural design of waste recycle for the application of a circular economy design. Specifically, we are considering an example of a one city building, investigating the architectural transformations of and average sized building and its zoning influence on the location of a local factory for a circular economy activity.

\subsection{Household waste}

Annually, worldwide, between 7,000 and 10,000 million tons of garbage are produced. From this average total, it is estimated that one-fifth is plastic garbage. In the case of Chile, on average, daily, $1.25 \mathrm{~kg}$ of garbage is produced per person, of which $90 \%$ is disposed of in landfills and $10 \%$ is recycled. Of the latter, $23 \%$ is sent to landfills, there are 47 in the country, and the remaining $77 \%$ goes to landfills, there are 38 in the country [8].

Santiago's Metropolitan Region (SMR) generates a total of 2,800,000 tons per year. The main source of waste generation in the SMR comes from the Metropolitan Region of Santiago. The capital city is responsible for more than 2 million tons per year, which are transferred to landfills. As seen in Fig. 1, this waste travels a range of 35 to 70 kilometers from its origin.

The large amount of garbage produced in Chile and in the Greater Santiago, given the high residential density, forces hundreds of tons per day to be moved a significant distance from its origin, a situation that generates impacts at various levels, such as the following: 


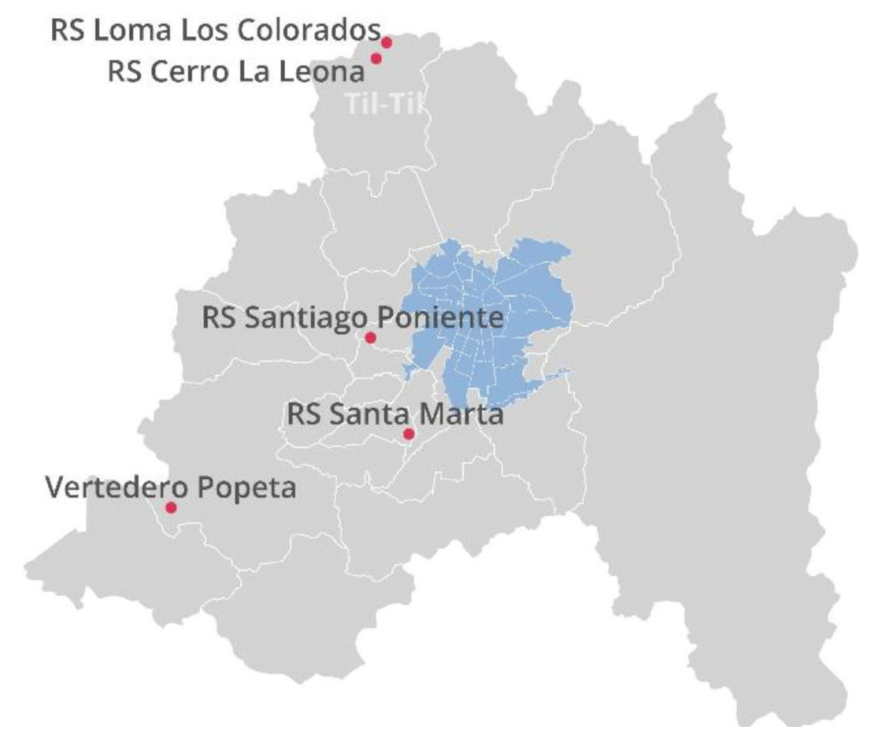

Figure 1: Map of Metropolitan Region, Santiago urban area and the location of its 5 landfills labelled as RS (Relleno Sanitario). (Source: Lucas Helle, 2017.)

- Increase in municipal spending for garbage removal service

- Higher energy consumption for transport and handling

- Fire risk

- Landfill collapses, affecting water and soil quality

- Risk of pests and diseases

- Invasion in the environment and impact on the quality of residents' life

- Resources and energy considered waste

- Wrongful practices of industries that work with garbage and landfills

\subsection{Combinatory of real estate \& waste locations}

Therefore, the main hypothesis of this work is that high-density buildings are an opportunity to introduce a small-scale alternative in order to better extract the maximum value from resources, recover and regenerate products and materials on-site. It seems of common-sense to design a process as close as possible to where the resources are used, as well as look into the architectural design of residential buildings, to evaluate the degree of needed adaption to transform high-density architecture into a local factory of circular economy. Focusing on a single case in the city of Santiago, as an exercise of adaptation, the aim is to develop a waste reducing design, with the possibility to redefine products and services. This exploration treats residential density as an opportunity to introduce a circular economic cycle on a local scale.

\section{THE 108 APARTMENTS CASE STUDY}

\subsection{Apartment household waste analysis in buildings}

As previously mentioned, the increasing number of apartments in restricted and expensive urban plots implies a higher housing density. This in turn means a significant accumulation 


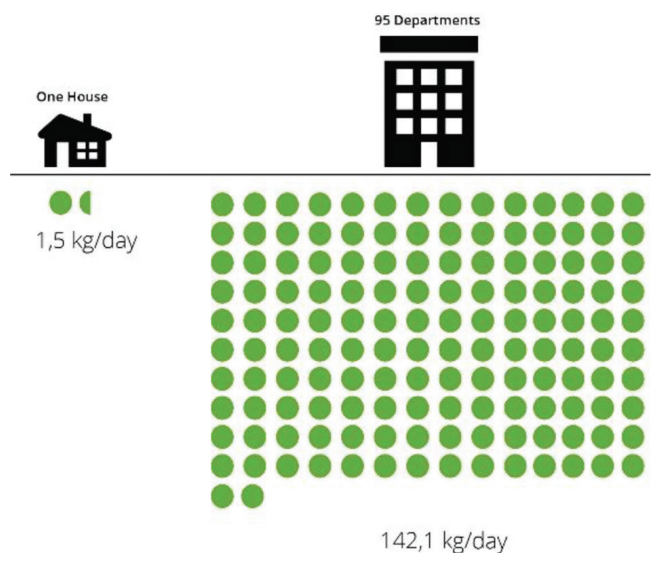

Figure 2: Diagram of waste production in kilograms per day for 4.5 households and a theoretical building of 95 apartments. (Source: Lucas Helle, 2017.)

of waste, in larger quantities and in smaller spaces. Would it be possible to take advantage of the spatial accumulation of waste that is produced and contained within a single architectural building?

The answer to this question will be addressed in two parts: first, its feasibility in terms of quantities and numbers; and second, its feasibility in terms of a spatial solution in the architectural design of high residential buildings.

Then, as illustrated by Fig. 2 and as previously explained, 4 to 5 households, where each produced 1.5 kilograms of waste per day, were replaced on average by a 95-apartment building which would produce approximately 142.1 kilograms per day. In a very general way, it has been estimated that a new building requires the demolition of approximately 4 to 5 houses. Thus, every new high-density building produces an estimated average of 21 times more waste than the previous existing houses.

At first glance, it seems feasible that communities residing in apartments, which produce the accumulation of garbage present a potentially favorable scenario to take advantage (of the resources that are currently considered waste).

\subsection{Waste quantities in high density buildings}

As a way to have more detailed information on the waste produced inside a building, and not solely the general averages detailed, waste was taken directly from a building. The analysis was based on a case study of a building with 108 households, slightly larger than the average 95 apartment building. In this building, a total of 5.2 medium size garbage bags of household waste are thrown away per hour. Just under half of the waste is comprised of organic material, then $1 / 5$ is glass, and almost $1 / 6$ is plastic [9].

The following Table 1 is the composition collected from the case study, according to a weight analysis of each element. The recollection of information was taken from 12 garbage bags, with a total weight of 12.95 kilograms.

The analysis of these waste composition values suggests that a process for management and handling of household waste could imply an income that exceeds operating cost, as long as the number of people involved in the system is greater than the threshold. In the most 
Table 1: Analysis of household waste per apartment

\begin{tabular}{lc}
\hline Waste type & \% per weight \\
\hline Organic & 42.1 \\
Glass & 19.6 \\
Plastic & 15.7 \\
Paper & 9.9 \\
Cardboard & 5.0 \\
Wood & 2.39 \\
Other & 1.40 \\
Textile & 1.38 \\
Plastic-coated carton containers & 1.35 \\
Metal & 0.61 \\
Aluminium & 0.57 \\
Organic & 42.1 \\
& $100 \%$ \\
\hline
\end{tabular}

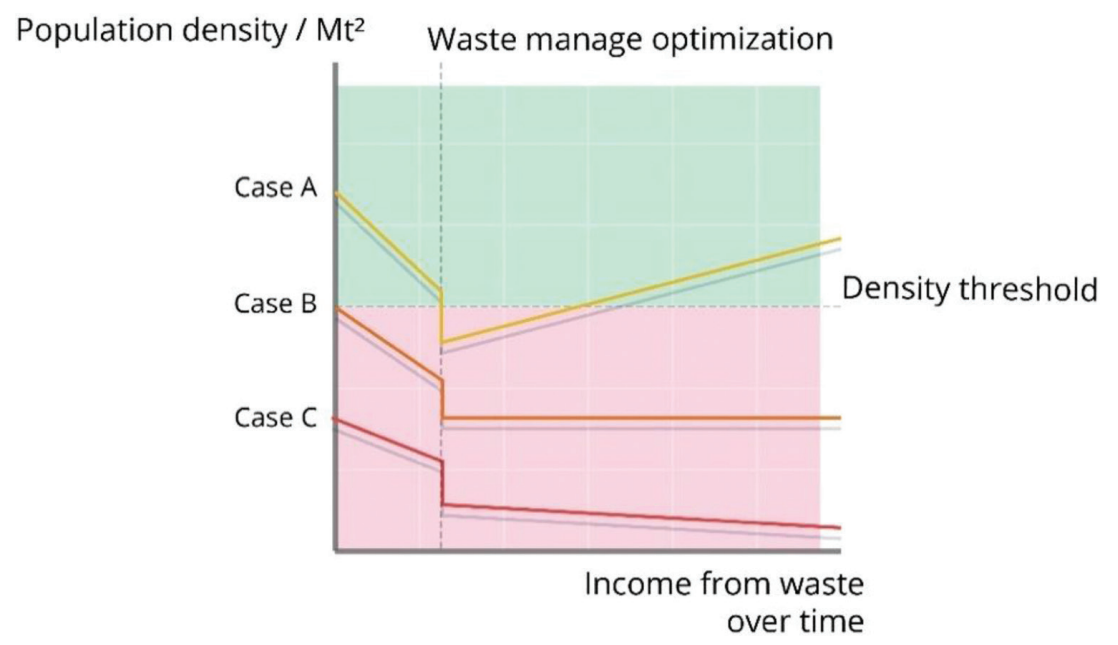

Figure 3: Three residential density thresholds. (Source: Helle, Lucas. 2017.)

favourable case, upon passing a density threshold, the waste would mean a positive income in the building's expenses along with a decrease in the collection and disposal of garbage [10].

Density can be proposed in a multi-dimensional approach. The conventional deals with the physical and esthetical appreciation of the architectural volume. The non-conventional determines the correct size for an affordable waste production. Such dimensional effort is shown in Table 2 by three types of residential density, in terms of people per square meter and income from waste over time.

Given that the increase in waste collection will be proportional to the increase in inhabitants' density, the overall is that it can potentially have a series of impacts such as: 
- Decrease in municipal spending for garbage removal service

- Lower energy consumption for transportation and handling

- Better handling in sanitary landfills

- Decrease in the amount of garbage produced

- Generation of a new market

- Less need for landfills

- Negative impact on informal garbage collectors

- Reduction of fixed costs in high-density communities.

\section{ECONOMIC VALUE OF WASTE}

Since household waste carries a value associated with its use as a resource, the capitalization of waste can be profitable through the corresponding processes. On one hand, organic waste is the main ecological risk of household produced garbage, since it contributes to landfill leakage. Conversely, it can be converted into fertilizer and if managed properly, generate biogas without causing major damage. Furthermore, the production of biogas from organic waste is an opportunity to generate electricity and heat.

Approximately, 15.99 cubic meters of biogas could be produced with 100 kilograms of organic waste [11]. Considering that a cubic meter of gas can produce $4.85 \mathrm{~kW} / \mathrm{h}$, the amount saved in electric bills would be about $\$ 7.750$ CLP in the current building's operating cost [10], as seen in Fig. 4.

On the other hand, the recycling of solid waste for sale as a raw material is a possibility to obtain a constant income. Although rubbish must be classified before being sold to thirdparty companies, the amount received by a building could be enough to pay for the needed classification. A building, which produces $100 \mathrm{~kg}$ of garbage a day, would obtain around $\$ 4.815$ CLP daily from selling the solid waste, depending on the media and composition (Table 2).

In summary, as shown in the previous figure and table, the total income calculated for a building of 108 apartments is $\$ 12.565$ per day $(\$ 7.750$ CLP $+\$ 4.815$ CLP), with a total of $\$ 4,586.225$ CLP year income, thus making a monthly revenue of $\$ 382.18$ for the building, and an average of \$ 3.539 CLP per apartment. As a reference, according to the Metropolitan Region Labour Observatory's (Observatorio Laboral para la Región Metropolitana) 2017 survey, the average salary of a residential building concierge is \$ 321.028 CLP. And the Chilean National Statistics Institute (INE, Instituto Nacional de Estadísticas) reported in 2016, with the Household Income Average Survey (Encuesta Suplementaria de Ingresos), that the monthly average income per household for the Metropolitan Region goes up to $\$ 1,219.200$ [12].

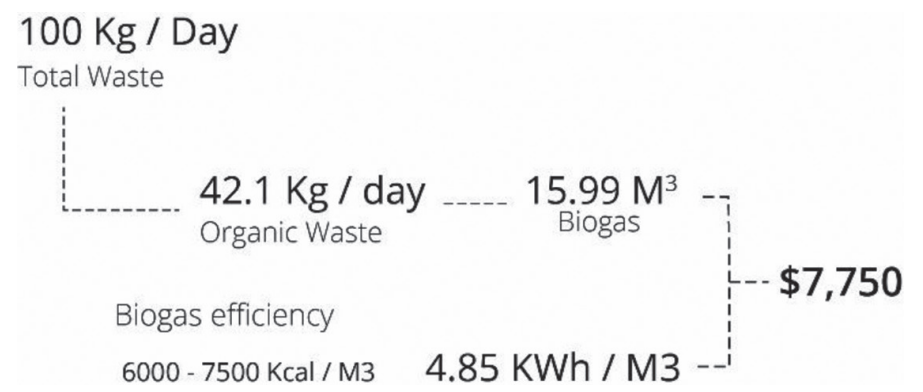

Figure 4: Biogas production on residential density and supposed income. (Source: Helle, Lucas. 2017.) 
Table 2: Waste price as recycling stock. (Source: Helle, Lucas. 2017. Also price values referenced to: http://www.t13.cl/videos/nacional/video-reportajes-t13-se-puedevivir-basura).

\begin{tabular}{llll}
\hline Material & Price (CLP) & Composition & $\begin{array}{l}\text { Value (CLP) } \\
{[100 \mathrm{~kg} / \text { day }]}\end{array}$ \\
\hline Plastic & $\$ .200 / \mathrm{kg}$ & $15.7 \%$ & $\$ 3.140$ \\
Paper & $\$ .100 / \mathrm{kg}$ & $9.9 \%$ & $\$ .990$ \\
Cardboard & $\$ .500 / \mathrm{kg}$ & $5.0 \%$ & $\$ .250$ \\
Aluminum & $\$ .500 / \mathrm{kg}$ & $0.57 \%$ & $\$ .285$ \\
Bottles & $\$ .5-.30$ & 10 pieces & $\$ .150$ \\
E-waste & $\$ .50 / \mathrm{kg}$ & - & - \\
Total & & & $\$ 4.815$ \\
\hline
\end{tabular}

\section{THE BUILDING AS A MACHINE / ORGANISM}

An apartment building can be understood as a machine that receives a constant input of resources, to operate. It has an output proportional to the resources it receives. Density is an opportunity to reduce investments in transportation and waste treatment. The current municipal spending on waste management can be redirected to subsidize the treatment and recovery of waste, which is more profitable than current expenses.

By these means, the building, in a generic sense of density, constitutes a particular way of organizing the space that condenses certain social attributes, locates activities making them feasible through its own infrastructure [13]. This is, thus, a spatial practice of applied circular economy design towards a different approach of understanding density. As the following Fig. 5 shows, a theoretical model of how to convert the input, and waste process of a building into an expression of circular micro economy. The incoming resources are potable water, gas,

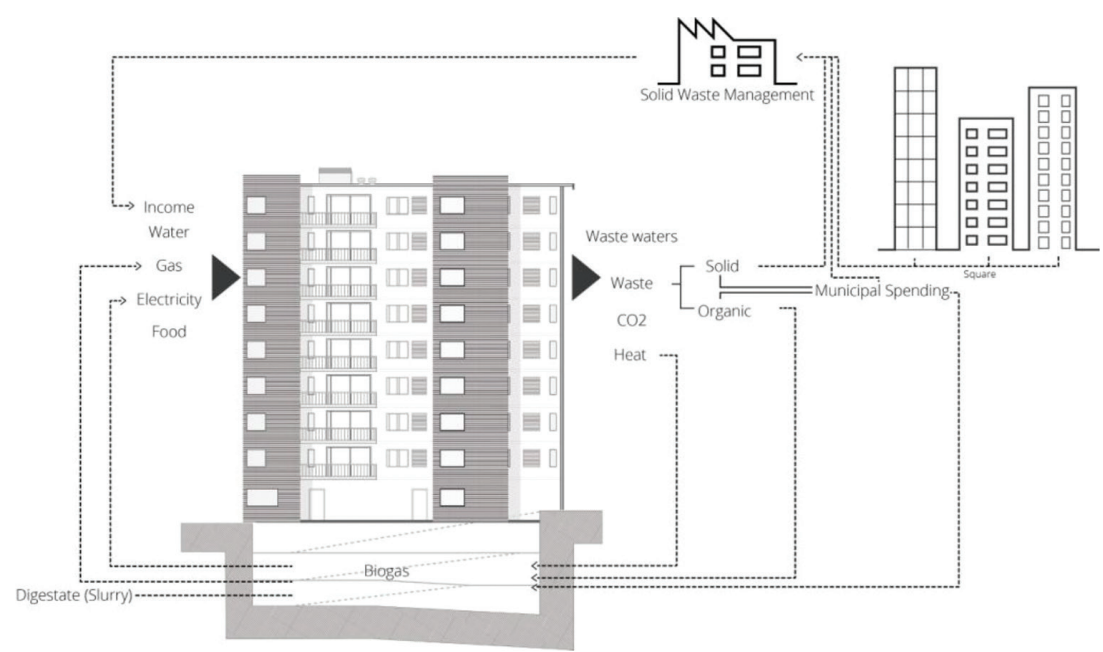

Figure 5: Diagram of waste production inside the building case study. (Source: Lucas Helle, 2017.)] 
electricity, and food for the households. Outgoing waste is grey and black wastewater, solid and organic waste, $\mathrm{CO}_{2}$ and heat. In the scheme, $\mathrm{CO}_{2}$ is not yet captured.

The circular economy outline assumes that heat is reinserted into the building and that most of the organic waste is treated onsite. Thus, resources from the process are recycled and reused within the building community. The remaining organic waste is handled by the municipality, with its respective budget. Thus, some solid waste, along with electronic scrap and other waste that cannot be processed, could be retrieved by the municipality and treated in a local waste treatment plant, which would receive rubbish from all buildings within the municipality.

The insertion of a waste processing system for buildings is proposed according to the scheme shown in Fig. 5. Through certain design changes to the building of the case study -which has quite a standardized architectural layout- it is possible to optimize the internal processes, so that the flow of resources is more profitable and sustainable in the long-term.

The possible straightforward scenario for an architectural definition of buildings in relation to household waste is explained in the following Fig. 6. On the one hand, the existing waste shaft is used to collect residential waste from households, separated by waste type. On the other hand, it shows the transformation of the conventional garbage room to accommodate a solid waste accumulator and separator, and a shaft for a solid waste accumulator. In this basic scenario, the building is able to process and recycle more than $36 \%$ of its solid waste within the building, which includes glass, paper, cardboard, tetra pack and aluminum. Approximately $21.5 \%$ of the waste is non-recyclable and must be retrieved by the municipality.

As for a more forward-looking scenario, which considers an advanced solid waste recovery plan, a greater alteration is proposed to the existing building. As shown in Fig. 7, a space of approximately $1,444 \mathrm{~m}^{2}$ is recommended to separate 10 tons per day of solid waste.

The total recycling in the set-up, suggested in Fig. 7, increases from 36\% to $46 \%$ of the waste, compared to the previous scenario. The recycling considers glass, paper, cardboard, plastic, wood, metal, tetra-pack (plastic-coated carton containers) and aluminum. In this setup, just $3.5 \%$ is not possible to recycle onsite and must, therefore, be taken by the municipality, compared to $21.5 \%$ from the previous setting.

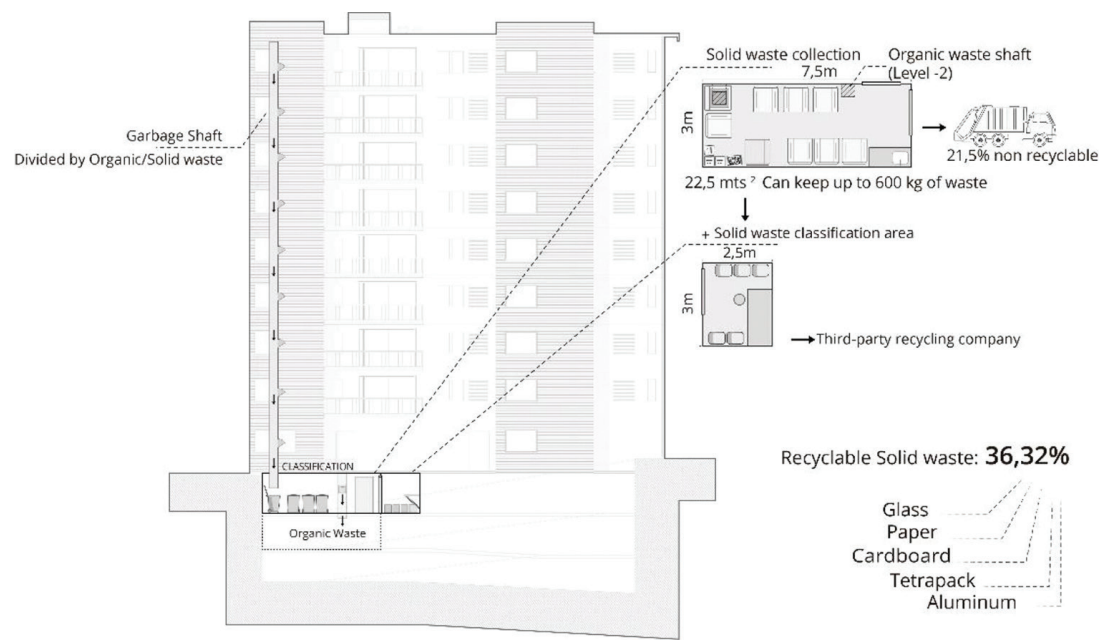

Figure 6: Diagram of waste production inside the building case study of recycling solid waste. (Source: Lucas Helle, 2017.)] 


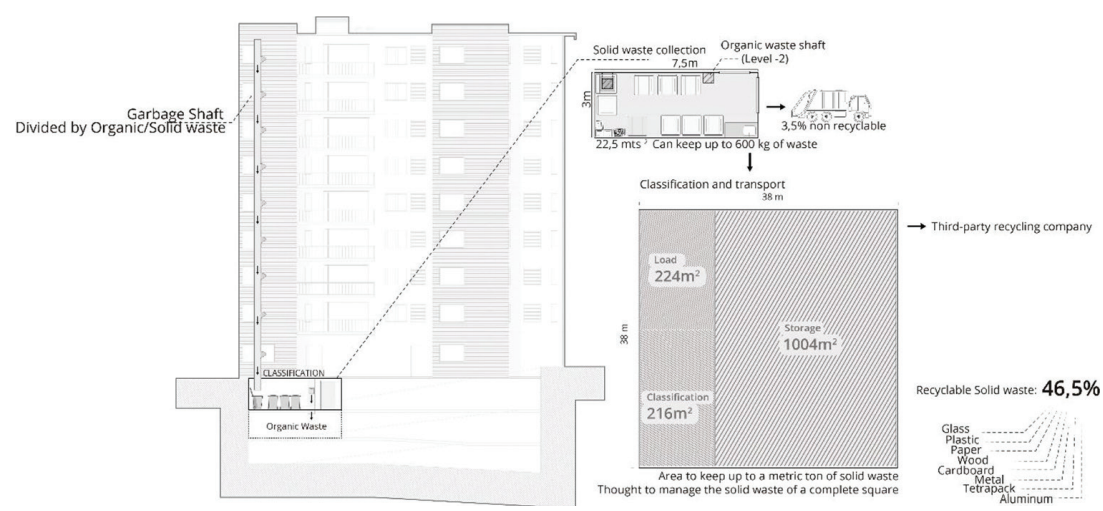

Figure 7: Diagram of waste production inside the building case study of recycling solid waste, considering an area to hold and process a metric ton of solid waste. (Source: Lucas Helle, 2017.)]

In the case of a third set-up of design adjustment to the building, the inclusion of a biodigester of organic waste for 50 kilos per day is considered, as shown in the following Figs 8 and 9. In this model, biogas is produced and provides energy for the building's boiler.This saves about $20 \%$ of daily energy consumption depending on the type of demand in the building and considering a daily use of $7.3 \mathrm{~kW} / \mathrm{h}$, which is the average consumption in the Metropolitan Region of Santiago de Chile. In total, it is estimated that up to a $96 \%$

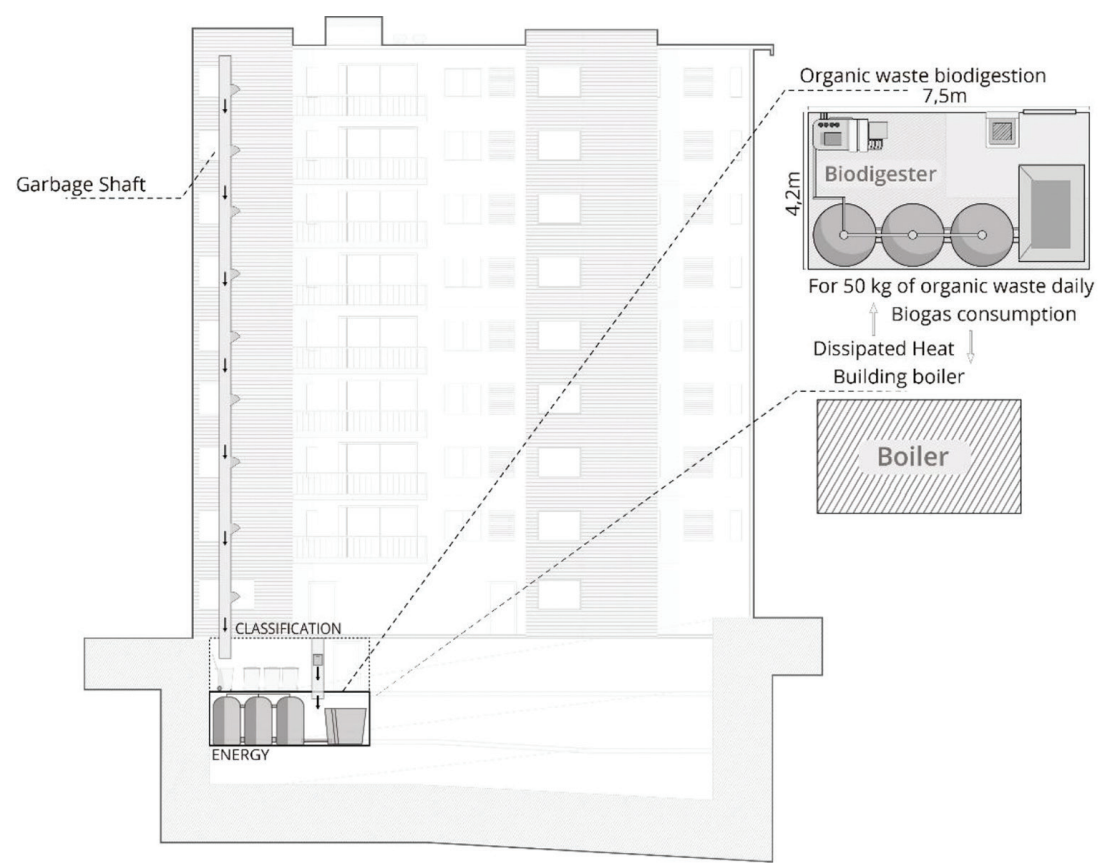

Figure 8: Diagram of waste production inside the building case study of recycling solid waste of the biodigester. (Source: Lucas Helle, 2017.) 


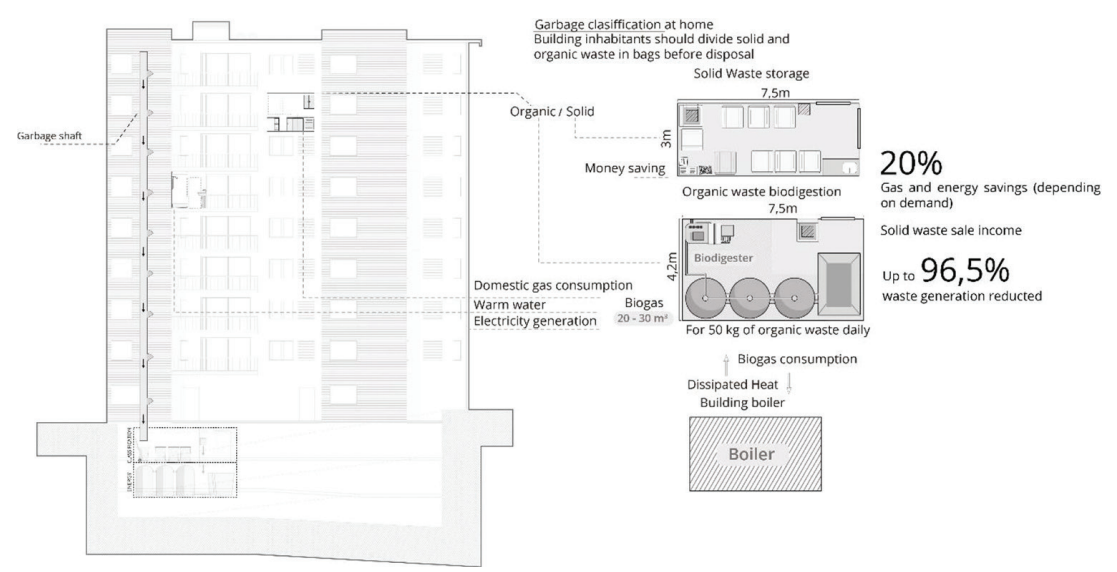

Figure 9: Diagram of waste production inside the building case study of recycling solid waste. (Source: Lucas Helle, 2017.)]

reduction in waste production can be achieved by combining both organic and solid waste management from inside the building. Thus, the inclusion of building inhabitants, in the process as consumers of energy, produced from their own waste, would reduce transportation expenses and municipal spending.

\section{CONCLUSIONS}

As seen from the quantitative analysis and the layout settings, the circular economy local design strategies would create important and positive outcomes such as:

- A considerable decrease in municipal spending for garbage removal service, as the amount of waste produced would diminish from $100 \%$, to $21.5 \%$ and potentially as low as $3.5 \%$. This increases municipal funds that could be allocated to co-finance the needed architectural alterations to the building.

- The range of design possibilities can accommodate diverse community needs and contexts, delivering a flexible array of options that can be met by contracts with the community, municipality, recycling companies and waste companies.

- Overall, the city would improve management of its sanitary landfills, and likely experience reduced demand for them, together with diminished effects of transportation costs (fiscal and environmental), which will be noteworthy, given their remote locations, as shown in Fig. 1.

- Reduction of living costs in high-density residential communities, through revenues generated by the circular economy design as a local level strategy.

- The example shows that with different levels of architectural interventions in existing buildings, a circular economy can improve waste problems to control then as well as to increase energy production, by reducing the overall costs of the tenants. 


\section{ACKNOWLEDGEMENTS}

This work was supported by the Centre for Social Conflict and Cohesion Studies (COES, CONICYT/FONDAP/15130009). I am especially grateful to Rodrigo Tisi, DesignLab's Research Director at Universidad Adolfo Ibáñez, who co-teaches Studio VIII with me, from which this research emerged, and the entire Centre for Territorial Intelligence Team which I feel grateful to lead. Even more, both, Rodrigo Tisi and I, are grateful to Lukas Helle academic work as our student whose work made this paper possible.

\section{REFERENCES}

[1] Contreras, Y., La recuperación urbana y residencial del centro de Santiago: Nuevos habitantes, cambios socio-espaciales significativos. EURE, 37(112), pp. 89-113, 2011. https://doi.org/10.4067/s0250-71612011000300005

[2] Abramo, P., La ciudad com-fusa: mercado y producción de la estructura urbana en las grandes metrópolis latinoamericanas. EURE, 38(114), pp. 35-69, 2012. https://doi.org/10.4067/s0250-71612012000200002

[3] López-Morales, E., Gentrificación en Chile: Aportes conceptuales y evidencias para una discusión necesaria. Revista de Geografia Norte Grande, 56, pp. 31-52, 2013. https://doi.org/10.4067/s0718-34022013000300003

[4] Contreras, Y., De los "gentries" a los precarios urbanos: Los nuevos residentes del centro del Santiago. EURE (Santiago) [online], 43(129), pp. 115-141, 2017. https://doi.org/10.4067/s0250-71612017000200006

[5] Garretón, M., City profile: actually existing neoliberalism in Greater Santiago. Cities, 65, pp. 32-50, 2017. https://doi.org/10.1016/j.cities.2017.02.005

[6] Lopez-Morales, E., 'Gentrification by ground rent dispossession: the shadows cast by large-scale urban renewal in Santiago de Chile. International Journal of Urban and Regional Research, 35(2), pp. 330-357, 2011. https://doi.org/10.1111/j.1468-2427.2010.00961.x

[7] Shertzer, A., Twinam, T. \& Walsh, R.P., Zoning and the Economic Geography of Cities. National Bureau of Economic Research (Working Paper 22658), 2016. https://doi.org/10.3386/w22658

[8] Porcentaje de residuos reciclados en Chile y proporción de basurales y rellenos sanitarios; Chile Ministerio de Medio Ambiente, available at http://www.santiagorecicla .cl/wp-content/uploads/2017/10/REPORTE-SOBRE-LA-GESTION-DE-RESIDUOSSOLIDOS-2014-RM1.pdf

[9] Valorización de residuos solidos domiciliarios en la región Metropolitana; Chile Ministerio de Medio Ambiente, available at http://www.santiagorecicla.cl/ wp-content/ uploads/2017/10/Gestion-y-Valorizacion-de-Residuos-Solidos- en-la-RM21121.pdf

[10] Tarifa de manejo de una tonelada de basura para la municipalidad de Providencia; Municipalidad de Providencia, available at http://www.providencia.cl/tramites-y-servicios2/ cuidado-ambiental/item/download/496_d98ce9813dd4276b58266caddcbbbc71

[11] Producción y eficiencia de biogás en Relleno Sanitario Loma los Colorados; Globalmetane, available at https://www.globalmethane.org/documents/events land_20110701_hirsch.pdf 
[12] Household Income Averages Survey INE's Encuesta Suplementaria de Ingresos 2016, available at http://www.ine.cl/docs/default-source/ingresos-y-gastos/esi/ ingreso-de-hogares-y-personas/resultados/2016/esi_sintesis_2016_rm.pdf?sfvrsn=4)

[13] Vergara Vidal, J., El Edificio de altura. Una revisión de las aproximaciones desde la sociología para su estudio. Revista de Urbanismo, 37, pp. 1-19, 2017.

https://doi.org/10.5354/0717-5051.2017.47059 